DOI: 10.35218/armca.2019.2.07

\title{
The Problem That Is not There: On the Old and New Interpretations of the Tent-Like Churches in Russian Architecture
}

\author{
Ivan Sablin*
}

\begin{abstract}
The article deals with the long-discussed problem of the so-called tent-like churches in Russian architecture (of the XVI to the XVII centuries), with all existing theories of their origin being considered, presenting two opposed views tentatively termed the isolationist and the internationalist ones, not excluding those, who tried to go away from this strict opposition. An attempt at the radical solution that rejects a traditionally accepted notion of this type's originality and uniqueness is made, with a proposal to take it instead for quite an ordinary variation of the eight-sided cloister vaults wide-spread in medieval architecture, that at times could be turned into these tents by simply straightening their otherwise curved constructions thus creating some kind of a pyramid. If properly investigated with all necessary parallels in Western architecture taken into account, even a search for the deeper symbolic meaning of this construction type (be that a holy place for the civil power representative or an allusion to St. Sepulchre) may become dispensable; this approach permits to treat instead the phenomenon as an incidental one caused by the mere formal and technical experiments and to a certain extent explicable by the intrusion of the Italian architects in the medieval Grand Duchy of Moscow.
\end{abstract}

Keywords. Tent-like churches, medieval architecture, early Renaissance, wooden structures, Russian art, Italian architects.

Hardly any question has been more actively discussed in the historiography of Russian medieval art than that of the origins of a particular shape of certain ecclesiastic buildings' vaults (dating from the XVI to the XVII centuries) known as the tent (uamëp in Russian). While so many other problems remain unresolved - often not even raised - such as the Transcaucasian or Arabic influences, origins of the multi-dome scheme, the

\footnotetext{
* $\mathrm{PhD}$, Faculty of Liberal Arts and Sciences of St. Petersburg State University, associate professor, Sablin@eu.spb.ru
} 
genesis of Russian iconostasis etc. - a lot of efforts is put into finding out possible sources of these indeed quite unusually looking buildings, which number is however limited to a dozen (if one excludes the later built less original derivates) and which originality may be contested.

This building type is paid so much attention to due to its definite opposition to the earlier constructive and spatial solutions adopted along with the Eastern Christian rites from Byzantium in the $\mathrm{X}$ century and little developed afterwards. This is a well-known type of the cross-in-square ${ }^{1}$ that prevailed for centuries in Greek-influenced lands, being directly imported to Russia; the fact that troubled generations of researches from the viewpoint of the hurt national pride. The tent-like churches were thus viewed as - if belated - reaction of Russian artists to these influences, as it seemed, definitely without a precedent ${ }^{2}$. The falseness of the latter statement I hope to make clear.

There are two opposed approaches to this problem that can be found in a quite voluminous historiography. One persists in denying any external influences on this type of Russian churches, the other tries to establish certain foreign parallels. Yet both the isolationists' and internationalists' (as the advocates of these approaches should be tentatively termed) concepts may or may not imply a kind of symbolism reaching beyond the mere formal (or technical) analogies. If they do they come closer to one another, forming a kind of "the third way", for which the borrowings are not as essential as the ideas that may lie beneath, hence the opposition (original vs. borrowed) becomes somewhat less acute.

The oldest and the most revered concept of the autonomous development of the tent-like churches is the one formulated in the late XIX century by Moscow historian I. E. Zabelin, whose research was quite promptly titled "the original features of Russian architecture"3. The tent was interpreted by him as being first elaborated by the carpenters, before being

\footnotetext{
${ }^{1}$ See Krautheimer, Richard, Early Christian and Byzantine Architecture, Penguin Books, Harmondsworth, 1965, p. 201 ff; Lange, Dorothea, "Theorien zur Entstehung der byzantinischen Kreuzkuppelkirche" in "Architectura", 16 (1986), S. 93-113. On RussianByzantin connections see: Комеч, А. И., Древнерусское зодчество конца X-начала XII в., Наука, Москва, 1987. The term is also anglicized (not quite happily indeed) as "cross-domed church" from German "die Kreuzkuppelkirche", directly adopted in Russian as well (крестовокуполный храм).

${ }^{2}$ A view generally accepted nowadays; its most concise formulation may be found $\mathrm{f}$. i. in the very first lines of Wikipedia entry dedicated to the tent-like churches (in Russian): Wampoвble храмы https://ru.wikipedia.org/wiki/\%D0\%A8\%D0\%B0\%D1\%82\%D1\%80\%D0\%BE\%D0\%B2\%D1 $\% 8 B \% D 0 \% B 5 \_\% 1 \% 85 \% D 1 \% 80 \% D 0 \% B 0 \% D 0 \% B C \% D 1 \% 8 B$ assessed on Aug 21, 2019. The passage may be translated (there is no English version) as "...stone tent-like churches... have no analogues in the architecture of the other lands".

3 Забелин, И. Е., “Черты самобытности в древнерусском зодчестве” in “Древняя и новая Россия”, 1878, No. 3, с. 185-203, №. 4, с. 282-303.
} 
given over to the stone builders. Thus a centuries-old problem of the architectural history was perhaps unintentionally touched upon; I cannot avoid mentioning it here, if somewhat schematically. At least twice it has come to the fore of the architectural thinking (with little chances for its inherent contradictions to be overcome). Once as a part of the Vitruvian tradition that explains all (decorative) features of classical orders as being derived from the carpentry ${ }^{4}$, for the second time as an attempt to interpret Gothic style as being more or less influenced by the wooden structures ${ }^{5}$ (or the woods simply as in the so-called pseudo-Rafael ${ }^{6}$ ).

Now that no-one could ever witness the proto-Doric wooden temple and that the most likely candidates for the precursors of the stone Gothic are found in Norway ${ }^{7}$ that is away from the birthplace of the style, the theory is developed with a reference to the perishability of the wooden structures, which thus could not survive from such remote times, yet those preserved (in the latter case of Norwegian stave churches) must be very close to the lost originals because of the supposed conservatism of building in $\operatorname{wood}^{8}$. No wonder that similarly the wooden tents in existence - the supposed "originals" - being all younger (XVII-XVIII centuries) than the stone "replicas", the explanation was that they most probably were close to the wooden churches built in the previous periods that subsequently influenced the stone constructions ${ }^{9}$. In fact there is an even more profound controversy of a reciprocal influence of the folk (rural) and high (urban) cultural strata ${ }^{10}$, where this particular problem of wood vs. stone is rooted.

Indisputably true is that for centuries the wood buildings prevailed in Russia thanks to the huge forests ready for use so that a little number of the preserved early stone structures (XI to XVI centuries) even if doubled (considering known or unknown losses) should be weighed against a bigger number of the settled places including the remote monasteries that all should

\footnotetext{
${ }^{4}$ See Rykwert, Joseph, The Dancing Column: On Order in Architecture, The MIT press, Cambridge (Mass.), 1996 for the detailed survey of the existing approaches to Vitruvian tradition.

${ }^{5}$ Horn, Walter, "On the Origin of the Medieval Bay System" in "Journal of the Society of Architectural Historians", Vol. 17. (1958), No. 2, p. 2-23.

${ }^{6}$ See Frankl, Paul, The Gothic: Literary Sources and Interpretations through Eight Centuries, Princeton University Press, Princeton, 1960, p. 271-278.

${ }^{7}$ Reiher, Herbert, Norwegische Stabskirchen: Meisterwerke germanischer Holzarchitektur, Verlag der Deutschen Zeitung in Norwegen, Oslo, 1944.

${ }^{8}$ Cf. on Shinto temples in Japan: Tange, Kenzo and Kawazoe, Noboru, Ise: Prototype of Japanese Architecture, M.I.T. Press, Cambridge (Mass.), 1965.

${ }^{9}$ See comprehensive criticism of Zabelin's views in: Ильин, М. А., Русское шатровое зодчество: Памятники середины 16 века. (Проблемы и гипотезы, идеи и образыл.), Искусство, Москва, 1980, с. 12 f.

${ }^{10}$ See Hauser, Arnold, Methoden moderner Kunstbetrachtung. Beck, München, 1970, S. 307405.
} 
have had many churches inevitably built of wood $^{11}$. They must have been gradually replaced with the stone structures, even the faintest memory of what they looked like being lost; what if they had crowning features similar to these stone tents? M. A. Ilyin, whose later views significantly differ from those under a discussion, in his earlier writings ${ }^{12}$ sided with Zabelin supposing additionally that the civil structures (fortress towers) must have had influenced the tents as well, given the local climate that made any sort of a high roof more viable than a flat cover. Interestingly this chance to segregate the motive of the tent from the ecclesiastic tradition was not really used by the Soviet researches, who in spite of the official atheism came somehow to terms with the fact that the earliest surviving monuments of Russian art were all commissioned by the church. The tent was rarely treated (let alone praised) as a secularization feature although it seems to be banned right because of that ${ }^{13}$.

There is another reason to share Zabelin's views: just like a preference for the straight entablature in the classical orders seems to be at odds with the nature of a stonework, the steep diagonals of the tents' slopes must have been derived directly from the almost prehistoric practice of putting wooden planks (or poles) together to make a conic shape, like some dwellings of the primitive peoples. That the stone vaults or the domes cannot be interpreted the same way seems obvious ${ }^{14}$. Curiously enough the term "tent" was used from the earliest time to designate these features in spite of belonging to a completely different area of the crafts. I am afraid, this dubious term choice caused a lot of confusion since "the tent" (just like baldachin or canopy in H. Sedlmayr's treatment of the Gothic cathedral ${ }^{15}$ ) implies flexible materials ready to take any shape, folded and unfolded, set up and removed. What is overlooked in these discussions is that the architectural tent to the contrary has an invariable shape of an eight-sided

\footnotetext{
${ }^{11}$ Multi-headed (head obviously stays here for a kind of the wooden turrets, not for a dome as otherwise) St. Sophia Cathedral is known to exist in Novgorod half a century before being burnt and replaced with a stone one. See its sketchy reconstruction in: Архитектурное наследие Великого Новгорода и Новгородской области, СПАС Лики России, СанктПетербург, 2008, с. 599.

${ }^{12}$ Ильин, М. А., Шатровое зодчество 16 века in the edition: История русского искусства. Т. 3. Изд-во АН СССР, Москва, 1955, с. 420-421.

${ }^{13}$ See Заграевский, С. В., "К вопросу о запрете патриарха Никона на строительство шатровых храмов" in “Журнал Томского государственного педагогического университета ПРАЕНМА. Проблемы визуальной семиотики”, №. 3 (13), 2017.

${ }^{14}$ Yet there were explanations of even this architectural feature being pre-formed by the carpentry, most ardently defended by J. Strzygowski in his highly controversial writings. See f. i. Strzygowski, Joseph, Spuren indogermanischen Glaubens in der Bildenden Kunst, C. Winter's, Heidelberg, 1936.

${ }^{15}$ Sedlmayr, Hans, Die Entstehung der Kathedrale, Atlantis Verlag, Zürich, 1950. Passim.
} 
pyramid $^{16}$. Those, who ignore this - not so unimportant! - number eight, must be seduced by the above-mentioned opposition of the innovative tents to the traditional domes. Be there 8,10 or 12 facets it does not matter since the decisive feature is the overall sharpness as opposed to a smooth spherical shape of the dome.

The theory of the wooden precursors has been significantly corroborated by the discovery in the 1940s of the previously overlooked chronicle that referred to the creation of supposedly the earliest example of a tent-like church, that of Ascension in Kolomenskoye; the passage goes like this: "built... in its upper part according to the wooden methods" 17 . Soon to follow the anti-cosmopolitism campaign of 1949 that severely damaged Russian art history as a whole used this statement to seal a discussion forever. Yet it seems that nowadays the majority of researches has somewhat lost interest in Zabelin's interpretation, even this chronicled proof is treated as too vague a statement to be interpreted unambiguously ${ }^{18}$.

The only other autochthon conception in existence is the one proposed by the researcher of Pskov architectural school (this city being a center of merchants free state that remained independent from Moscow until the early XVI century), Y. P. Spegalsky ${ }^{19}$. A native of this city he emphasized an importance of Pskov masons (whose presence in Moscow is reported on many occasions) in the development of the Russian state architectural style. He discovered parallels in some tent-like churches (primarily the one in the village Ostrov by Moscow) with the chronologically nearest examples of Pskov school where the cross-in-square type had been equally abandoned. Yet the most striking similarity found is that of the stepped arches supporting the domes ${ }^{20}$, which alone would never produce a

\footnotetext{
${ }^{16}$ The only exception to this rule is St. Cosmas and Damian church in Murom, which presentday complex crowning feature is in fact a result of the recent, very questionable repairs; the original tent being lost long ago. What remains of it is a 16-sided foundation, which could in fact easily carry a standard eight-sided tent. See Ильин, М. А., Русское шатровое зодчество, с. $106 \mathrm{f}$.

${ }^{17}$ In Russian: «Поставил церковь... вверх на деревянное дело» (Тихомиров, М. Н., Малоизвестные летописные памятники 16 в. in the edition Исторические записки, Институт истории АН СССР, Москва, 1941, т. 10, с. 88.)

${ }^{18}$ Ильин, М. А., Русское шатровое зодчество, С. 36; Баталов, А. Л., О происхождении шатра в русском каменном зодчестве 16 века in the edition Древнерусское искусство: Идея и образ. (Опыты изучения византийского и древнерусского искусства.), Северный паломник, Москва, 2009, с. 59.

${ }^{19}$ Спегальский, Ю. П., Каменное зодчество Пскова, Стройиздат, Ленинград, 1976, с. 45 ff. A concept was first proposed by F. F. Gornostaev in: Горностаев Ф. Ф. Новые формы зодчества «Царственной Москвы» in the edition История русского искусства. Изд. И. Кнебель, Санкт-Петербург, 1911, т. 2, с. 23-33.

${ }^{20}$ A surprising fact is that these constructions find an unexpected precursor in the XII century Provencal Romanesque churches, f. i. in Avignon cathedral. Conant termed this feature "encorbled arches" (Conant, Kenneth John, Carolingian and Romanesque architecture, 8001200. Penguin books, Baltimore, 1959, p. 149).
} 
unique shape of the tent though. Spegalsky was clearly opposed to the wooden version of Zabelin insisting on the independence of masonry in the history of architecture ${ }^{21}$. His local patriotism ${ }^{22}$ was hardly compatible with the general pattern of Russian art history that treated all Russian territories as being from the time unknown culturally one and the same area - in spite of political differences. However Pskov's school may in a way be considered one of many external (non-Moscow) influences that we are going to trace further.

If Byzantium never produced anything similar to the pyramidal composition of the tent-like churches, it makes sense to investigate other regions of Eastern Christianity before continuing westwards. Serbian churches, which brief blossoming coincided with an hiatus in the development of Russian architecture (due to the Tatar invasion), are often quoted as a source for the changes that occurred here in the late XIV to mid$\mathrm{XV}$ century, when the stone architecture slowly recovered ${ }^{23}$. A step-like composition of certain Russian churches seems to be similar to those of the southern neighbor; yet not a single trace of anything tent-like was found there $^{24}$ ! (However it is of note that long before Russians Serbs arrived at abandoning the cross-in-square scheme.)

Even more uncertain were the references to Oriental influences, the most elaborate being the one that paralleled the tents to the Georgian or Armenian churches with their cone-shaped crowning features ${ }^{25}$. The latter as is well-known - hid traditional domes raised over no less traditional crossin-square building below. However, the gravest mistake in my opinion was that the number eight by no means would have come out of these features even if the cones (like their tambours) could be multi-faceted rather than round. A mentioning of this hardly possible parallel only testifies to the complexity of the tent-like churches problem.

Interestingly, if the fact that the "tents" of Transcaucasian architecture are not visible from the inside was the main reason for

${ }^{21}$ Спегальский, Ю. П., Каменное зодчество Пскова, с. 45.

${ }^{22}$ Further represented by: Морозкина, Е. Н., Церковное зодчество древнего Пскова. Зодчество Пскова как наследие. Северный паломник, Москва, 2007.

${ }^{23}$ Брунов, Н. И., К вопросу о ранне-московском зодчестве in the edition Труды секиии археологии Института Археологии и Искусствознания РАНИОН, т. 4, Москва, 1928, с. 93-106; Мальцева, С. В., Балканские влияния или параллели в древнерусской архитектуре? in the edition Актуальные проблемы теории и истории искусства, НППринт, Санкт-Петербург, 2012, т. 2, с. 137-144.

${ }^{24}$ Serbian influence as a counterweight to Zabelin's views predominant in the early $20^{\text {th }}$ century Russian art history were first proposed by N. I. Brunov in a lecture summarized in: Alpatov, Mikhail and Brunov, Nikolai, "Nachrichten aus Moskau" in "Byzantinische Zeitschrift", 1924, Bd. 24 (3-4), S. 493-494.

${ }^{25}$ Султанов, Н. В., Русские шатровые иеркви и их соотнотение к грузино-армянским пирамидальным покрытиям in the edition Tpyды V археологического съезда в Тифлисе в 1881 2. Типография А.И. Мамонтова и Ко, Москва, 1887, с. 230-244. 
abandoning this version, it is true that only the $16^{\text {th }}$ century tent-like churches had the tents visible inside as well as outside. The later (post-Time of troubles) ones had their tents hidden by simpler vaults - the same happened with wooden churches, where such a situation is explained by the need to optimize interior heating in severe wintertime, thus all wooden as well as all later stone tents degraded to mere decorations that made the church look bigger outside than it really is (the same happened with bell-towers, whose tents were spared by the reforms of the 1660s). Yet, while in some cases the church in Putinki in Moscow - small tents really turned into some sort of pinnacles - other structures retained the hollowness of the tents thus producing a unique (almost an absurd) situation of the small church interiors being topped by something like an attic under the tent, a space which was unused and empty. Yet, excluding these "fake" tents - as Ilyin has done in his comprehensive and influential study ${ }^{26}$ - does not help to solve the chief problem.

Serbian, Georgian, Armenian - let alone Indian or Arabic ${ }^{27} !-$ influences being of little interest, the researches inevitably have turned their eyes toward the West. The choice was between the Southern (early Renaissance) and the Northern (Gothic) influences. That the Italian architects were active in Russia almost a century long could never be denied, yet a popular explanation that had them comply with the local tastes to the extent of making their creations different from anything built about the same time in Italy lies near and in fact was and is used by all isolationists ${ }^{28}$. As for Gothic trends, they are even more difficult to determine, for despite all economic contacts, hardly anything Gothic could be built then in Pskov, Novgorod ${ }^{29}$, let alone Moscow.

In older days, the term "Gothic" was used to designate everything that was post-classical or medieval ${ }^{30}$; later on, a more cautious approach permitted references to certain Gothic-like elements, most usually the general notion of verticality. This feature is what makes Serbian churches unlike those of Byzantium, yet even in the architecture of the declining empire, similar motives could be found (the church in Arta!), due partly to the direct contacts with the West during the time of the Fourth crusade ${ }^{31}$.

\footnotetext{
${ }^{26}$ Ильин, М. А., Русское шатровое зодчество.

${ }^{27}$ The opinion supported by Viollet-le-Duc in: Viollet-le-Duc, Eugène, L'art russe, ses origines, ses éléments constitutifs, son apogée, son avenir. Ve A. Morel et Cie, Paris, 1877, p. 113.

${ }^{28}$ Seе Лашкарев, П. А., Религиозная монументальность. Изд. Университетской типографии, Киев, 1866, с. 86; Снегирев, И. М., Памятники Московской древности, Тип. Август Семен, Москва, 1842, тетр. 1, с. 27.

${ }^{29}$ With one notable exception being that of Bishop's palace in Novgorod that is an example of the Brick Gothic thanks to German masons' participation.

${ }^{30}$ Ильин, М. А., Русское шатровое зодчество, с. 10.

${ }^{31}$ Krautheimer, Richard, Early Christian and Byzantine Architecture, p. 291 ff.
} 
Let it be made clear. Verticality permeates most of the buildings created in Russia long before the emergence of tent-like vaults. The pre-Tatar school of Vladimir and Suzdal, Pskov churches, early Moscow churches may all stupefy a foreign visitor with a very specific impression that I would try to explain by referring to the metaphor of a pit, a deep and narrow space that directs visitors' attention towards the heaven represented by the dome above. Longitudinal Western churches (as well as certain cathedrals here, created or influenced by the Italians), despite their immense height, they would never produce such a unique impression due to the fact that their verticality is outweighed and softened by their development in length. Thus, we approach another universal opposition of central vs. longitudinal or even a more general one of vertical vs. horizontal dwelling upon which is not possible here.

What makes the new type of church different from those earlier examples of verticality is that most churches are devoid of inner partitions, being pillarless ${ }^{32}$. Sometimes, rather than dividing a bigger space into separate yet interconnected parts by introducing slender supports (a logic of the cross-in-square church), independent interiors were gathered to produce an ensemble of churches - that is how Moscow Intercession cathedral-on-theMoat (St. Basil) came into existence. Due to inner partitions, earlier churches had a less acute "pit" impression, while the newer ones resulted from the rejection of the cross-in-square type. Not that the latter was found antiquated (or alien), rather there is a worldwide feature of structural (and technical) progress in building that is to eliminate inner supports, covering as much space as possible with a single vault. Pillarless churches have already been mentioned in Serbia and Pskov; the so-called pillar-like (Sic! столпообразные $e^{33}$ ) churches as well as the cross-like vault ${ }^{34}$ (крещатый not to be mixed with - much better known - cross vault, крестовый in Russian) are testimonies of the same tendencies in Moscow of the early $16^{\text {th }}$ century. The latter type is of a particular interest, as it may be treated as a transformation of the cross-in-square type by omitting inner supports, replaced with the elements of a cloister vault.

When the cloister (or domical) vault emerged in Russia is yet a moment to be fixed. Yet it is clear that the uniqueness of tent-like churches will become somewhat less striking as soon as people realize that the elusive

\footnotetext{
${ }^{32}$ The only exception is the cathedral of the Northern monastery from Solovki islands, which has lost its tent (seе Ильин, М. А., Русское шатровое зодчество, c. $100 \mathrm{ff}$.).

33 Ibid. С. 20 ff.; Некрасов, А. И., Проблема происхождения древнерусских столпообразных храмов in the edition Труды кабинета истории материальной культуры, 1-й Моск. гос. ун-т. Ист.-философ. фак. и Фак. литературы и искусства, Москва, 1930, вып. 5, с. 17-50.

${ }^{34}$ Суслов, В. В., Взгляд на одну из форм наружного покрытия древнерусских иерквей in the edition Суслов, В. В., Очерки по истории древнерусского зодчества... Тип. А. Ф. Маркса, Санкт-Петербург, 1889, с. 5-18.
} 
stone tent is nothing but a special case of this quite wide-spread vaulting type. Incompatible with the Gothic, whose constitutive element is obviously a ribbed groin-vault opposed by its very nature to any modifications of the cloister one, it was revived by Renaissance architects (the so-called "dome" of Florence cathedral being the best-known example) as previously by Romanesque ones. It seems that the eight-sided variation of a cloister vault has esthetic advantages over the one built on a square foundation. I make a conjecture that a very short distance separates the eight-sided cloister vault from the pure tent-vault, the shorter one than may be presumed by those who believe the tent-like churches had no precedent.

It is of interest how superficial knowledge of the non-Russian architectural phenomena sometimes misled the researchers in their most sincere attempts to find parallels for the Russian tents. The case of Transcaucasian cones being already discussed, the other example is Nekrasov's (who in the beginning did not deviate from Zabelin's views ${ }^{35}$ ) mentioning of Western spires as being very close to Russian tents. In fact, some of them, made of stone and hollow inside, are really tents with a different (sharper) angle and invisible from the interior, in this respect closer to the "degraded" tents of the $17^{\text {th }}$ century. However, the only example that this researcher favored in particular is in fact the result of an obvious lack of information. The pyramidal crowning of Gelnhausen church choir ${ }^{36}$ in Germany (a building of late Romanesque style with Gothic elements) is made of wood and tops a typical early Gothic ribbed vault inside! The researcher may have had no experience with that monument misled by a poor quality reproduction.

Nowadays, a similar blunder is to be found in a publication by A. L. Batalov with a new interpretation of the Ascension church (and its followers) being proposed ${ }^{37}$. His reference to Pisa architectural school involves mentioning of three structures - the baptistery, St. Sepulchre church and St. Agatha chapel - the latter being small and insignificant, thus omissible, two others being of little relevance, given their peculiar forms (and early date, the $12^{\text {th }}$ century). The "tent" of the baptistery ${ }^{38}$ has a unique conic shape that is

\footnotetext{
${ }^{35}$ Некрасов, А. И., Проблема происхождения древнерусских столпообразных храмов in the edition Труды кабинета истории материальной культуры, с. 17. Cf. later views of the same art historian in: Некрасов, А. И., Очерки по истории древнерусского зодчества 11-17 веков. Изд-во всесоюз. Акад. арх-ры, Москва, 1936, c. 9.

${ }^{36}$ Некрасов, А. И., Проблема происхождения древнерусских столпообразных храмов in the edition Труды кабинета истории материальной культуры, с. 41.

${ }^{37}$ Баталов, А. Л., О происхождении шатра в русском каменном зодчестве 16 века in the edition Древнерусское искусство, с. 55-74.

${ }^{38}$ See Pierotti, Piero, Benassi, Laura, Deotisalvi: l'architetto pisano del secolo d'oro, Pacini, Pisa, 2001.
} 
hidden from view by the inner dome (the section drawing used by Batalov ${ }^{39}$ omits this feature), the overall solution being of no consequences for the architectural history.

As for St. Sepulchre church, a published drawing ${ }^{40}$ is erroneous again; judging things based on personal experience, I insist on its crowning being not a real tent, but a cloister vault with quite visible curves. Hence the possibility of finding a tent-like church in the $12^{\text {th }}$ century Italy (built on eight pillars with a wooden roof over the surrounding lower gallery) is diminished. The cloister vault must be easier to construct, while esthetically a pure tent deprived of upper light gives an unpleasant dark impression in its central (uppermost) part, no wonder it was avoided (with one notable exception to be mentioned further); the opening in the upper part, a kind of a lantern is possible (found in Russia from Intercession cathedral on), in the West it has been used for functional purposes only - see later. Batalov equally quotes (this time with a correct drawing ${ }^{41}$ ) the famous Florentine baptistery, where the pyramidal roof (of a lower angle) hides a perfect example of a cloister vault. The idea that it could be kind of stretched up to produce a tent is not as primitive as it seems. It makes sense to try to find the examples of the eightsided cloister (i. e. curved) vaults in Russia, which can be done - see later. Batalov's general idea belongs to the third "symbolic" group which is to be discussed later.

Now the very fact of Italians' involvement in the tent-like churches construction is disputable. There were times when for want of any exact references, researchers tended to believe these churches were rather a local reaction to imported innovations. Intercession cathedral's legendary creators are known as Barma and Postnik, not Italian names for sure ${ }^{42}$, the latter supposedly from Pskov. Yet earlier churches may have been built by foreigners. An almost tent-like church in Dyakovo ${ }^{43}$ (by Kolomenskoye) with its weird plan gives little chances of arriving at any satisfactory interpretation $^{44}$, if failing to find the closest parallel in a drawn plan for a church $^{45}$ that accompanies a manuscript of Filarete's treatise (the first Italian

\footnotetext{
${ }^{39}$ Баталов, А. Л., О происхождении шатра в русском каменном зодчестве 16 века in the edition Древнерусское искусство, с. 61.

${ }^{40}$ Ibid, c. 65.

${ }^{41}$ Ibid, c. 60.

${ }^{42}$ Contrary to the earlier opinion in: Даль, Л. В., “Историческое исследование памятников русского зодчества" in “Зодчий”, 1873, №. 1, с. 6.

${ }^{43}$ Ильин, М. А., Русское шатровое зодчество, с. $56 \mathrm{ff}$.

${ }^{44}$ See Булкин, В. А., Итальянизмьв в древнерусском зодчестве конца XV-XVI вв. in the edition Вестник Ленинградского университета. Сер. Ист., яз., лит, Изд-во Ленингр. ордена Ленина ун-та, Ленинград, 1973, вып. 4, с. 59-66.

${ }^{45}$ Filarete's treatise on Architecture Being the Treatise by Antonio di Piero Averlino, Known as Filarete, Transl. with an introd. a. notes by Spencer, John R., Yale univ. press, New Haven, London, 1965, vol. 2 (Facsimile), book 14, folio $108 \mathrm{r}$.
} 
to arrive here was Aristotle Fioravanti, Filarete's friend mentioned in his treatise $^{46}$ ). Now Petrok the Minor as of recent identified with Pietro Annibale from Florence ${ }^{47}$ is considered to be the Ascension church's architect ${ }^{48}$ (there is a date on it "1532" made in Arabic digits then unused in Russia ${ }^{49}$ ).

A recent controversy occurred regarding the dating of Alexandrovo sloboda (nowadays Alexandrov) tent-like Trinity church, which, if placed at the beginning of the $16^{\text {th }}$ century, would predate Ascension church, thus being the earliest example of this type in Russia. Its modest appearance leads to questioning if the first example of anything can be a complete realization of its idea or the latter needs some preparatory tentative steps. The priority of Trinity church first suggested by Nekrasov ${ }^{50}$ was later developed by W. W. Kavelmacher, who found archeological evidence for this redating ${ }^{51}$, criticized however by the majority of the colleagues ${ }^{52}$. The most important fact is that this church if indeed built in the early $16^{\text {th }}$ century may be ascribed to the recorded activity of a certain Italian architect in this monastery, which like Kolomenskoye was a kind of a suburban residence of Moscow grand dukes (later czars). Alvise di Montagnana ${ }^{53}$ or Aleviz the $\mathrm{New}^{54}$ is a prominent builder, the first to introduce the classical order features in Russia, when designing St. Michael cathedral in Moscow Kremlin.

\footnotetext{
${ }^{46}$ Ibid., vol. 1, p. 180, 202, 217.

${ }^{47}$ Sее Кивимяэ, Ю. Ю., Пётр Фрязин или Пётр Ганнибал? Итальянский архитектор в позднесредневековой Руси и Ливонии in the edition Крепость Ивангород: Hовые открытия, Дмитрий Буланин, Санкт-Петербург, 1997, с. 236-245.

${ }^{48}$ See Подъяпольский, С. С., Архитектор Петрок Малой in the edition Памятники русской архитектуры и монументального искусства: Стиль, атрибуции, датировки, Наука, Москва, 1983, с. 34-50.

${ }^{49}$ Published by Гаврилов, С. А., Церковь Вознесения в Коломенском. (Исследования 19721990 гг.) in the edition Реставраиия и архитектурная археология: Новые материалы и исследования, Мейкер, Москва, 1991, с. 170-171.

${ }^{50}$ Некрасов, А. И., Древние Подмосковныя: Александровская слобода, Коломенское, Измайлово, Т-во В. В. Думнов, насл. бр. Салаевых, Москва, 1923, с. 15.

${ }^{51}$ Кавельмахер, В. В., Церковь Троицы на Государевом дворе древней Александровой слободы in the edition Памятники архитектуры древней Александровой слободы, Золотые ворота, Владимир, 1995, с. 19-74; Заграевский, С. В., Новые исследования памятников архитектуры Александровской слободы, АЛЕВ-В, Москва, 2008.

${ }_{52}$ Баталов, А. Л., Памятники Александровой слободы в контексте развития русской архитектуры 16 века in the edition Зубовские чтения, СТР-Принт, Струнино, 2005, вып. 3, c. 29-41 considers however the English masons' involvement in its construction.

53 As discovered by Подъяпольский, С. С., Венецианские истоки архитектуры московского Архангельского собора in the edition Древнерусское искусство: Зарубежные связи, Наука, Москва, 1975, с. 275-278, who has also shown the profound connections of Moscow buildings of this architect with the Venetian traditions.

${ }^{54}$ It is of note that Kolomenskoye church once has been ascribed to this architect as well. See Булкин, В. А., О иеркви Вознесения в Коломенском in the edition Культура средневековой Руси (Посвящается 70-летию М.К. Каргера), Наука, Ленинград, 1974, с. 113-116. Aleviz had to remain in Moscow for an extended period of time - for which there is no evidence - to be able to participate in the construction of this church. What however if he made his contribution to the creation of the tent-like type in a different way? See below.
} 
Of even greater importance can be a (relatively small) cathedral of High St. Peter (Vysokopetrovsky) monastery in Moscow (see Fig. 1), its architect being most probably the same Aleviz ${ }^{55}$ ! This must be the earliest example of the octagonal centre crowned with the cloister vault. "Pulling" it up one would get a perfect version of the tent. Was it not possible that the same architect followed this advise in his other creation ${ }^{56}$, that is in Alexandrovo? This cathedral has an additional no less striking feature in its ground plan, which is an octafoil, a figure that surfaces from time to time in different regions of Christianity, its sporadic existence is yet to be researched in all details. The apses of the Moscow cathedral are of varying size, the main ones on the world sides (including the one directed to the East that contains an altar, three others have doorways) being bigger than the intermediary ones. The difference is slighter than say in a church at Kvetera monastery in Georgia (the $10^{\text {th }}$ century) a perfectly preserved example of this type with four apses so small that one is lured to consider it a special case of quadrifoil, a type with its own history. A bigger Georgian octafoil at Ninotsminda monastery (the late $6^{\text {th }}$ century) collapsed in the $19^{\text {th }}$ century, it had unequal apses as well (partly survived as a ruin).

Some ruined churches ${ }^{57}$ of this type can be found in Armenia (or present-day Turkey), better preserved are Romanesque churches in the West. The oldest one ( $10^{\text {th }}$ century?) at Ošlje ${ }^{58}$ in Croatia locally called "rotunda" is heavily ruined, yet the other at St. Michel d'Entraygues (by Angoulême) in France (see Fig. 1) was restored in the $19^{\text {th }}$ century, its upper part results from this intervention; the same happened with the so-called Rotunda in VladimirVolynsky (present day Ukraine), where again there is a variation in size of the eight apses. The churches in Georgia and Armenia have (or had) domes, as for the French and Ukranian monuments, their original crowning features are hard to determine, the one in Croatia may have had a dome (judging by

\footnotetext{
55 Дедушенко, Б. П., К истории ансамбля Высоко-Петровского монастыря in the edition Древнерусское искусство XVII в., Наука, Москва, 1964, вып. 4, С. 253-271. Previously this monument was considered to be an example of the early baroque style, due to its similarity with certain buildings of the late XVII to early XVIII century in fact built in imitation of this cathedral. There is still an uncertainty if this Aleviz was the same, who built Moscow Kremlin cathedral and worked in Alexandrovo sloboda though. I personally find no reasons to put it in question.

${ }^{56} \mathrm{Seе}$ Саблин, И. Д., Деятельность итальянских архитекторов в России на рубеже XVXVI веков: K проблеме происхождения шатрового зодчества in the edition Образы Италии в России-Петербурге-Пушкинском Доме, Изд. Пушкинского дома, СанктПетербург, 2014, вып. 2., с. 21-31.

${ }^{57}$ See Strzygowski, Joseph, Die Baukunst der Armenier und Europa, A. Schroll \& Co., Wien, 1918, Bd. 1, S. 131 f., Bd. 2, S. 490 f. Especially on the influence of Armenian architecture on European buildings including those mentioned here.

${ }^{58}$ Vežić, Pavuša, "Dalmatinski šesterolisti - Sličnosti i razlike" in "Ars Adriatica", No. 2, 2012, s. 41-74. (See s. 50-51 for this particular monument; article deals otherwise with a unique local group of hexafoils, wide-spread in pre-romanesque Dalmatia.)
} 
similar hexafoils). Santa Maria degli Angeli in Florence from the mid- $15^{\text {th }}$ century considered to be a work of Brunelleschi ${ }^{59}$ has a simplified crowning feature (against the original design), its lower part is on the contrary too complex to be interpreted as an octafoil (cf. the architectural drawings of Leonardo $^{60}$, influenced by this building). Yet a more interesting findings may be done, if one leaves the area of the places of worship turning to functional buildings.

There is another blunder to ascertain. This time, in S. Zagraevsky, Kavelmacher's son, who continued his father's researches of Alexandrovo sloboda. He has made a reference to the unique building still in existence in France approximately dating back to the $12^{\text {th }}$ century. This is a monastic kitchen situated at Fontevrault abbey (see Fig. 1) and first published by Viollet-le-Duc ${ }^{61}$. Yet a section drawing to be found in his Dictionary is not quoted by Zagraevsky, who used modern exterior photograph instead ${ }^{62}$ that gives little chances to realize the complexity of the monument. It seems that such kitchens ${ }^{63}$ were more than just auxiliary structures, they must have had a greater significance. It would in fact corroborate Kavelmacher's theory, were Zagraevsky to consider this building's striking similarity to Russian tent-like churches! Trinity church in Alexandrovo was part of a refectory created according to Russian tradition to have refectories built with their own churches, for which the refectory served as a kind of a nave. Now Fontevrault kitchen was surely separate from the initial (as well as the existing) refectory yet put very close to it. It has a unique system of vaults (reminiscent of Muslim structures but of little importance for the buildings in question) that permitted ventilation for the stoves placed within the apse-like projections. They are six in all, another one being destroyed when a new refectory was put close to it, the eighth would have been impossible as an entrance is in its place.

\footnotetext{
${ }^{59}$ Syed, Anna, "Brunelleschis Oratorium von Santa Maria degli Angeli zwischen liturgischer Nutzung und architektonischem Anspruch" in "Zeitschrift für Kunstgeschichte", No. 4, 2010, S. 487-306.

${ }^{60}$ See Lang, S., "Leonardo's Architectural Designs and the Sforza Mausoleum" in "Journal of the Warburg and Courtauld Institutes", vol. 31, 1968, p. 218-233.

${ }^{61}$ Viollet-le-Duc, Eugène, Dictionnaire raisonné de l'architecture française du XIe au XVIe siècle, t. 4, Édition Bance-Morel, Paris, 1860, p. 461-486. Of interest is a reconstruction of the lost kitchen at Marmoutier abbey by Tours (Ibid, p. 462-463), which is a six-foil, another type with its unique place in European architecture.

62 Заграевский, С. В., Происхождение древнерусского шатрового зодчества: Возвращение к проблеме, Электронная библиотека «РусАрх», Москва, 2015. Seе Заграевский, С. В., Новые исследования памятников архитектуры Александровской слободы http://www.zagraevsky.com/sloboda_book5.htm (assessed on Aug. 23, 2019). The same happened previously with Nekrasov, who mentioned it very briefly in: Некрасов, А. И., Проблема происхождения древнерусских столпообразных храмов in the edition Tруды кабинета истории материальной культуры, с. 45-46.

${ }^{63}$ For some obscure reason, Zagraevsky mentioned certain "breweries" along with the kitchens, a statement that is repeated at the above-quoted Wikipedia site.
} 
Yet the plan of this kitchen retains features typical for the octafoils as those already mentioned while the main (central) chimney is a perfect tent! There are other monastic kitchens still preserved (all built at a later time), one in Glastonbury having a cloister vault with clearly visible curves, one (palatial not monastic and from the late $15^{\text {th }}$ century) at Portugal Sintra with two cones, not eight-sided pyramids; two further kitchens are simplified versions of the one at Fontevrault, the earlier one at the Pamplona cathedral in Northern Spain, the later one (the $14^{\text {th }}$ century) is a part of Avignon papal palace. These two have tent-like chimneys built over the rectangular plans using a kind of the pendentives.

Now, could it be that the Italian Alvise imitated a lower part of Fontevrault kitchen in High St. Peter monastery and its upper part at Alexandrovo cloister's refectory? Since there are no chances of proving the architect's acquaintance with either Western monument (all quite remote from his native Montagnana), it is but a mere conjecture that some interconnection of all these monuments may have existed. Additionally, there are early Christian baptisteries in Northern Italy, their central octagons being surrounded by juxtaposed rounded and rectangular niches (Novara, Lomello, Chieri all with the cloister vaults); these monuments are close to the area of activity of Italian architects, who mainly came to Russia. But again, the possibility of direct influence is minimal.

However, a Fontevrault experiment may have led to the creation of the only known example of pure tent in Western ecclesiastic architecture ${ }^{64}$ never mentioned so far in the context of Russian art. Yet, they still exist in the same Loire valley as the above-mentioned Fontevrault kitchen. The church at Loches has a unique external as well as internal appearance thanks to its pyramidal spires (built in line over a longitudinal interior), hollow and open into the interior. If one needs to find a birthplace of tent-like churches, it is here. This marginal, inconvenient, strangely-looking type of vaulting happened to be of use in the kitchens in the West... and of interest in Russia due to its opposition to the domes and its definite verticality.

Batalov proposed a different explanation for the Western sources that he believed to find in the above-mentioned Pisa buildings ${ }^{65}$. He wanted it to be a direct reference to the Anastasis rotunda in Jerusalem, whose earliest (the $4^{\text {th }}$ century) version has been reconstructed with a wooden cone open in

\footnotetext{
${ }^{64}$ That is how in my opinion a certain modern architect (Auguste Perret) may have arrived at the unusual solution used for his biggest ecclesiastic creation, St. Joseph church in le Havre, not through his visits to Russia in the 1930s! There is a kind of the tent-like structure made of ferroconcrete that tops this building giving it a truly signpost appearance in a cityscape.

${ }^{65}$ Баталов, А. Л., О происхождении шатра в русском каменном зодчестве 16 века in the edition Древнерусское искусство; see also Баталов, А. Л. и Беляев, Л. А., Церковь Вознесения в Коломенском: Архитектура, археология, история, МГОМЗ, Москва, 2013.
} 
the middle ${ }^{66}$. Now, that there is still a wooden dome-like structure, it does not matter for Batalov, as his is the opinion that the plan is more decisive than what is above, a view that I sincerely support. Only that circle and octagon are not the same figures for sure! St. Sepulchre church in Pisa being a rare exception to the rule that most of the churches with this dedication are circular (rotundas). Equally, Pisan baptistery is unusual in that it is circular rather than implying a number eight (as a reflection of the baptism as the $8^{\text {th }}$ day of creation idea ${ }^{67}$ ). Florentine baptistery as a more typical example may also include a reference to the Dome of the rock in Jerusalem that some pilgrims reported to be the remnant of the Jewish Temple ${ }^{68}$. Finally, I do not agree with these parallels in Moscow churches, the eight-sided structures are so wide-spread in the world that their symbolic value should be put aside in favor of more general - formal or technical - ones.

Kolomenskoye church is in fact one of many European examples, yet the first Russian one that Anastasis rotunda copies ${ }^{69}$ - with its Greek-cross plan, no internal galleries, and octagonal tent - is really hard to believe. Were it an imitation of a particular Pisa church, it would have more similarities, they are limited here to number eight though. Therefore Batalov's version cannot be accepted.

Yet another example of symbolic interpretation, however excluding Western parallels (and simultaneously rejecting Zabelin's theory), can be found in what remains the most all-encompassing book on this type (if limited to the monuments from the $16^{\text {th }}$ century), the already mentioned concluding essay of Ilyin. So brilliant his research is in its analysis of the particular buildings in question, his lack of interest for non-Russian parallels as well as a resulting general concept are hard to accept.

His was a view of the tent being a ciborium, yet not one raised over early Christian altars, but rather in accordance with the local tradition of the so-called "czar's place" in the cathedral ${ }^{70}$, an original (made of wood in fact) construction for the most revered among the faithful (since the galleries was abandoned earlier, grand dukes or czars prayed on the same level with the

\footnotetext{
${ }^{66}$ See Dehio, Georg and von Bezold Gustav, Kirchliche Baukunst des Abendlandes, Verlag der Cotta'schen Buchhandlung, Stuttgart, 1887, Atlas 1, Taf. 13.

${ }^{67}$ See Krautheimer, Richard, "Introduction to an Iconography of Medieval Architecture" in "Journal of the Warburg and Courtauld Institutes", 1942, No. 5, p. 1-33. This researcher was however of the opinion that any non-orthogonal plan could stay for the rotunda in the mind of the medieval man.

${ }^{68}$ See Sinding-Larsen, Staale, St. Peter's Chair in Venice in the edition Art, the Ape of Nature (Studies in honor of H. W. Janson), H. N. Abrams, New York, 1981, p. 43-46.

${ }^{69}$ A surprisingly close imitation of St. Sepulchre Church was in fact built in Resurrection New Jerusalem cloister by Moscow in the late $17^{\text {th }}$ century (by which time the replicas of this building had disappeared from European architectural theory and practice). Its conical cover of the rotunda (which may be similar to Pisa baptistery initial appearance) has since collapsed and of its appearance very little may be conjectured.

${ }^{70}$ Ильин, М. А., Русское шатровое зодчество, с. $37 \mathrm{ff}$.
} 
rest of the laymen). This was a kind of an attempt of a new religiosity or rather a state religion; obviously, such churches remained rare, experimental, mostly created in private manors not for everyone's use (Red square Intercession cathedral being an exception). A quite inspired explanation, yet if put next to the above quoted examples - and not to the rare wooden ciboria - it loses most of its attractiveness. The Italian influences were not quoted by Ilyin, who preferred to leave Ascension church (for him the first example of this type) without either an author or a precedent. A wonderful creation that came out of the blue.
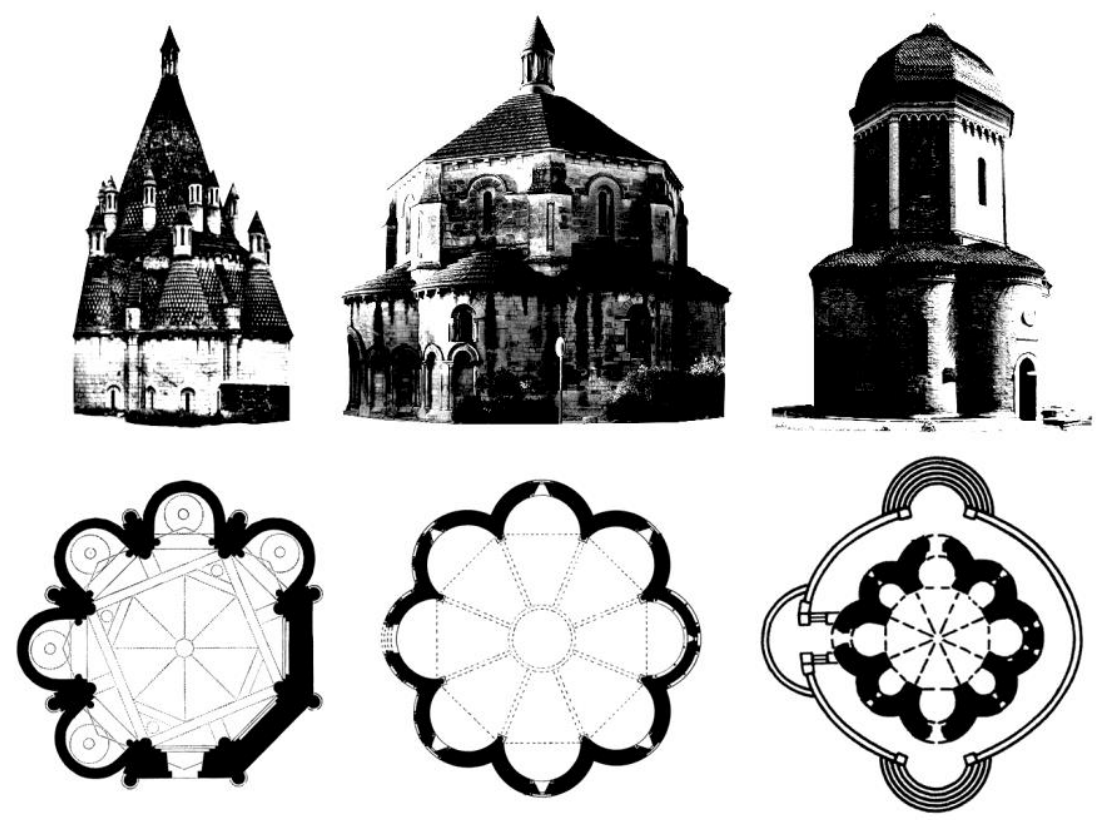

Fig. Examples of octafoils in European architecture. Left to right: Fontevrault abbey kitchen, church in St. Michel d'Entraygues (both France, $12^{\text {th }}$ century), and cathedral at Vysokopetrovsky cloister in Moscow $\left(16^{\text {th }}\right.$ century) (plans not to scale, East approx. to the right)

What I have tried to develop is a concept of relative triviality of the type in question, being - let it be stated again - an inconvenient and rare variety of a well-known eight-sided cloister vault. Once banned from use in its radical form, it continued in Russian architecture for one more century as a simple cloister vault over octagonal tambours, for which many (mostly provincial) examples can be found (e.g. the late $17^{\text {th }}$ century cathedral at Pererva monastery by Moscow that is in fact visible from the high bank of 
the river, where Kolomenskoye church looms). To summarize, there is no special problem of tent-like churches in Russia, rare as they are, the examples of this type can be found elsewhere. Taking them into account, one ceases to see anything special about this group of Russian buildings. The monuments are unique, not the type as such.

\section{Bibliography:}

Alpatov, Mikhail and Brunov, Nikolai, "Nachrichten aus Moskau" in Byzantinische Zeitschrift, 1924, Bd. 24 (3-4), S. 493-494.

Баталов, А. Л., "О происхождении шатра в русском каменном зодчестве 16 века" in the edition Древнерусское искусство: Идея и образ. (Опыты изучения византийского и древнерусского искусства.), Северный паломник, Москва, 2009, c. 55-74.

Баталов, А. Л., “Памятники Александровой слободы в контексте развития русской архитектуры 16 века" in the edition Зубовские чтения, СТР-Принт, Струнино, 2005, вып. 3, с. 29-41.

Баталов, А. Л. и Беляев, Л. А., Церковь Вознесения в Коломенском: Архитектура, археология, история, МГОМЗ, Москва, 2013.

Брунов, Н. И., "К вопросу о ранне-московском зодчестве" in the edition Tpyдbl секиии археологии Института Археологии и Искусствознания РАНИОН, т. 4, Москва, 1928, с. 93-106.

Булкин, В. А., "Итальянизмы в древнерусском зодчестве конца XV - XVI вв". in the edition Вестник Ленинградского университета. Сер. Ист., яз., лит, Издво Ленингр. ордена Ленина ун-та, Ленинград, 1973, вып. 4, с. 59-66.

Булкин, В. А., "О церкви Вознесения в Коломенском" in the edition Культура средневековой Руси (Посвящается 70-летию М.К. Каргера), Наука, Ленинград, 1974, c. 113-116.

Conant, Kenneth John, Carolingian and Romanesque architecture, 800-1200. Penguin books, Baltimore, 1959.

Даль, Л. В., "Историческое исследование памятников русского зодчества" in “Зодчий”, 1873, No. 1, с. 6.

Дедушенко, Б. П., "К истории ансамбля Высоко-Петровского монастыря" in the edition Древнерусское искусство XVII в., Наука, Москва, 1964, вып. 4, С. 253-271.

Dehio, Georg and von Bezold, Gustav, Kirchliche Baukunst des Abendlandes, Verlag der Cotta'schen Buchhandlung, Stuttgart, 1887, Atlas 1.

Frankl, Paul, The Gothic: Literary Sources and Interpretations through Eight Centuries, Princeton University Press, Princeton, 1960, p. 271-278.

Гаврилов, С. А., “Церковь Вознесения в Коломенском. (Исследования 19721990 гг.)" in the edition Реставрачия и архитектурная археология: Новые материалы и исследования, Мейкер, Москва, 1991, с. 170-171.

Горностаев Ф. Ф., Новые формы зодчества «Царственной Москвыл» in the edition История русского искусства. Изд. И. Кнебель, Санкт-Петербург, 1911, T. 2, c. 23-33.

Hauser, Arnold, Methoden moderner Kunstbetrachtung, Beck, München, 1970. 
Horn, Walter, "On the Origin of the Medieval Bay System" in "Journal of the Society of Architectural Historians", Vol. 17. (1958), No. 2, p. 2-23.

Ильин, М. А., "Шатровое зодчество 16 века" in the edition: История русского искусства. Т. 3. Изд-во АН СССР, Москва, 1955, с. 420-421.

Ильин, М. А., Русское шатровое зодчество: Памятники серединь 16 века. (Проблемы и гипотезы, идеи и образы.), Искусство, Москва, 1980.

Кавельмахер, В. В., “Церковь Троицы на Государевом дворе древней Александровой слободы" in the edition Памятники архитектуры древней Александровой слободы, Золотые ворота, Владимир, 1995, с. 19-74.

Кивимяэ, Ю.Ю., "Пётр Фрязин или Пётр Ганнибал? Итальянский архитектор в позднесредневековой Руси и Ливонии" in the edition Kpenocmь Ивангород: Hовые открытия, Дмитрий Буланин, Санкт-Петербург, 1997, с. 236-245.

Комеч, А. И., Древнерусское зодчество конца X - начала XII в., Наука, Москва, 1987.

Krautheimer, Richard, Early Christian and Byzantine Architecture, Penguin Books, Harmondsworth, 1965.

Krautheimer, Richard, "Introduction to an Iconography of Medieval Architecture" in Journal of the Warburg and Courtauld Institutes, 1942, No. 5, p. 1-33.

Lang, S., "Leonardo's Architectural Designs and the Sforza Mausoleum" in Journal of the Warburg and Courtauld Institutes, vol. 31, 1968, p. 218-233.

Lange, Dorothea, "Theorien zur Entstehung der byzantinischen Kreuzkuppelkirche" in Architectura, 16 (1986), S. 93-113.

Лашкарев, П. А., Религиозная монументальность. Изд. Университетской типографии, Киев, 1866.

Мальцева, С. В., “Балканские влияния или параллели в древнерусской архитектуре?" in the edition Актуальные проблемь теории и истории искусства, НП-Принт, Санкт-Петербург, 2012, т. 2, с. 137-144.

Морозкина, Е. Н., Церковное зодчество древнего Пскова. Зодчество Пскова как наследие. Северный паломник, Москва, 2007.

Некрасов, А. И., Древние Подмосковныл: Александровская слобода, Коломенское, Измайлово, Т-во В. В. Думнов, насл. бр. Салаевых, Москва, 1923.

Некрасов, А. И., Очерки по истории древнерусского зодчества 11-17 веков. Изд-во всесоюз. Акад. арх-ры, Москва, 1936.

Некрасов, А. И., "Проблема происхождения древнерусских столпообразных храмов" in the edition Труды кабинета истории материальной культуры, 1-й Моск. гос. ун-т. Ист.-философ. фак. и Фак. литературы и искусства, Москва, 1930, вып. 5, с. 17-50.

Pierotti, Piero, Benassi, Laura, Deotisalvi: l'architetto pisano del secolo d'oro, Pacini, Pisa, 2001.

Подъяпольский, С. С., “Архитектор Петрок Малой” in the edition Памятники русской архитектуры и монументального искусства: Стиль, атрибуции, датировки, Наука, Москва, 1983, с. 34-50.

Подъяпольский, С. С., "Венецианские истоки архитектуры московского Архангельского собора" in the edition Древнерусское искусство: Зарубежные связи, Наука, Москва, 1975, с. 275-278.

Reiher, Herbert, Norwegische Stabskirchen: Meisterwerke germanischer Holzarchitektur, Verlag der Deutschen Zeitung in Norwegen, Oslo, 1944. 
Rykwert, Joseph, The Dancing Column: On Order in Architecture, The MIT press, Cambridge (Mass.), 1996.

Sedlmayr, Hans, Die Entstehung der Kathedrale, Atlantis Verlag, Zürich, 1950.

Sinding-Larsen, Staale, St. Peter's Chair in Venice in the edition Art, the Ape of Nature (Studies in honor of H. W. Janson), H. N. Abrams, New York, 1981, p. 4346.

Strzygowski, Joseph, Die Baukunst der Armenier und Europa, A. Schroll \& Co., Wien, 1918.

Strzygowski, Joseph, Spuren indogermanischen Glaubens in der Bildenden Kunst, C. Winter's, Heidelberg, 1936.

Syed, Anna, "Brunelleschis Oratorium von Santa Maria degli Angeli zwischen liturgischer Nutzung und architektonischem Anspruch" in "Zeitschrift für Kunstgeschichte", No. 4, 2010, S. 487-306.

Саблин, И. Д., “Деятельность итальянских архитекторов в России на рубеже XV-XVI веков: K проблеме происхождения шатрового зодчества" in the edition Образы Италии в России-Петербурге-Пушкинском Доме, Изд. Пушкинского дома, Санкт-Петербург, 2014, вып. 2., с. 21-31.

Снегирев, И. М., Памятники Московской древности, Тип. Август Семен, Москва, 1842, тетр. 1, с. 27.

Спегальский, Ю. П., Каменное зодчество Пскова, Стройиздат, Ленинград, 1976.

Суслов, В. В., "Взгляд на одну из форм наружного покрытия древнерусских церквей" in the edition Суслов, В. В., Очерки по истории древнерусского зодчества... Тип. А. Ф. Маркса, Санкт-Петербург, 1889, с. 5-18.

Султанов, Н. В., "Русские шатровые церкви и их соотношение к грузиноармянским пирамидальным покрытиям" in the edition Tpydbl $V$ археологического съезда в Тифлисе в 1881 г. Типография А.И. Мамонтова и Ко, Москва, 1887, с. 230-244.

Tange, Kenzo and Kawazoe, Noboru, Ise: Prototype of Japanese Architecture, M.I.T. Press, Cambridge (Mass.), 1965.

Тихомиров, М. Н., “Малоизвестные летописные памятники 16 в.” in the edition Исторические записки, Институт истории АН СССР, Москва, 1941, т. 10, с. 88.

Шатровые храмь

https://ru.wikipedia.org/wiki/\%D0\%A8\%D0\%B0\%D1\%82\%D1\%80\%D0\%BE\%D0 $\% B 2 \% D 1 \% 8 B \% D 0 \% B 5 \_\% D 1 \% 85 \% D 1 \% 80 \% D 0 \% B 0 \% D 0 \% B C \% D 1 \% 8 B$ assessed on Aug 21, 2019.

Vežić, Pavuša, "Dalmatinski šesterolisti - Sličnosti i razlike" in Ars Adriatica, No. 2, 2012, s. 41-74.

Viollet-le-Duc, Eugène, Dictionnaire raisonné de l'architecture française du XIe au XVIe siècle, t. 4, Édition Bance-Morel, Paris, 1860.

Viollet-le-Duc, Eugène, L'art russe, ses origines, ses éléments constitutifs, son apogée, son avenir. Ve A. Morel et Cie, Paris, 1877, p. 113.

Забелин, И. Е., “Черты самобытности в древнерусском зодчестве” in “Древняя и новая Россия", 1878, №. 3, с. 185-203, No. 4, с. 282-303.

Заграевский, С. В., “К вопросу о запрете патриарха Никона на строительство шатровых храмов" in “Журнал Томского государственного педагогического университета ПРАЕНМА. Проблемы визуальной семиотики”, №. 3 (13), 2017. 
Заграевский, С. В., Новые исследования памятников архитектуры Александровской слободы, АЛЕВ-В, Москва, 2008.

http://www.zagraevsky.com/sloboda_book5.htm (assessed on Aug. 23, 2019).

Заграевский, С. В., Происхождение древнерусского шатрового зодчества: Возвращение к проблеме, Электронная библиотека «РусАрх», Москва, 2015.

Архитектурное наследие Великого Новгорода и Новгородской области, СПАС Лики России, Санкт-Петербург, 2008, р. 599.

Filarete's treatise on architecture being the Treatise by Antonio di Piero Averlino, known as Filarete, Transl. with an introd. a. notes by Spencer, John R., Yale univ. press, New Haven, London, 1965. 